\title{
Correction to: Unrecognized implementation science engagement among health researchers in the USA: a national survey
}

Elizabeth R. Stevens ${ }^{1 *}$, Donna Shelley ${ }^{1,2}$ and Bernadette Boden-Albala ${ }^{3}$

\section{Correction to: Implementation Science Communica-} tions (2020) 1:39

https://doi.org/10.1186/s43058-020-00027-3

Following publication of the original article [1], it was reported that a supplemental appendix (Additional file 1) was missing. The missing appendix is included in this Correction article.

\section{Supplementary information}

Supplementary information accompanies this paper at https://doi.org/10. 1186/s43058-020-00056-y.

Additional file 1. Relevant analysis survey questions.

\section{Author details}

'Department of Population Health, NYU Langone Health, New York, NY, USA. ${ }^{2}$ College of Global Public Health, NYU, New York, NY, USA. ${ }^{3}$ Susan and Henry

Samueli College of Health Sciences, UC Irvine, Irvine, CA, USA.

Published online: 15 July 2020

\section{Reference}

1. Stevens ER, Shelley D, Boden-Albala B. Unrecognized implementation science engagement among health researchers in the USA: a national survey. Implement Sci Commun. 2020;1:39. https://doi.org/10.1186/s43058020-00027-3.

The original article can be found online at https://doi.org/10.1186/s43058 020-00027-3

*Correspondence: Elizabeth.stevens@nyulangone.org

${ }^{1}$ Department of Population Health, NYU Langone Health, New York, NY, USA

Full list of author information is available at the end of the article

(c) The Author(s). 2020 Open Access This article is licensed under a Creative Commons Attribution 4.0 International License, which permits use, sharing, adaptation, distribution and reproduction in any medium or format, as long as you give appropriate credit to the original author(s) and the source, provide a link to the Creative Commons licence, and indicate if changes were made. The images or other third party material in this article are included in the article's Creative Commons licence, unless indicated otherwise in a credit line to the material. If material is not included in the article's Creative Commons licence and your intended use is not permitted by statutory regulation or exceeds the permitted use, you will need to obtain permission directly from the copyright holder. To view a copy of this licence, visit http://creativecommons.org/licenses/by/4.0/ The Creative Commons Public Domain Dedication waiver (http://creativecommons.org/publicdomain/zero/1.0/) applies to the data made available in this article, unless otherwise stated in a credit line to the data. 